This is pre-print version of an article whose final and definitive version has been published in Global Media and Communication.

The article is available online at https://doi.org/10.1177/1742766517694472

\title{
Naturalising the New Cold War \\ The geopolitics of framing the Ukrainian conflict in four European newspapers
}

\begin{abstract}
The conflict in Ukraine has prompted analyses about the return of cold war divisions to Europe. Thus, this study focuses on the role the news media plays in the conflict by examining how the visual and textual practices of news framing help constitute geopolitical rationality and legitimise foreign policy. We analyse how the framing of the conflict in Die Welt, Dagens Nyheter, Helsingin Sanomat and The Guardian developed through four key events between February 2014 and February 2015. The analysis indicates that by promoting particular news frames the newspapers contributed to the legitimation of European Union policies, which are premised upon supporting the Ukrainian government in its military campaign in eastern Ukraine and placing responsibility for the conflict onto Russia. Hence, we argue that the news framing eventually contributed to the naturalisation of the new cold warIDVDJHRSROLWLFDOUDWFieRIQMQWdWagitimising foreign policy in Europe.
\end{abstract}

Key words: Ukrainian conflict, geopolitics, newspapers, framing

\section{Introduction}

With over 9,000 deaths, 20,000 injured, more than 1,6 million people displaced domestically and internationally and 5 million in need of humanitarian assistance (European Commission, 2016), the Ukrainian crisis has become the largest humanitarian tragedy Europe has witnessed since the 1990Is wars in the Balkans. While having complex roots in UkrainH IIV SR-k\&hmunist developments, including continuous power struggles between competing oligarchs, weak state structures, a poor economy and profound inequality and social insecurity (Ishchenko, 2014; Wilson, 2009), the conflict also has major international dimensions. Hence, against a background of longstanding disputes between Western powers and Russia concerning the economic and military alignment of formerly 
socialist countries and Soviet states - and the eastward spread of both the EU and NATO (Haukkala, 2015; Sakwa, 2015), the close involvement of perceived superpower interests in Ukraine have rendered geopolitical interpretations integral elements in explaining the Ukrainian conflict (e.g. Legvold, 2014; Rutland, 2015; Wade, 2015). As the United States and the EU, on one hand, and Russia, on the other, have aligned with opposite sides of the warring camps LQ8NUDLQHDQHZFROG

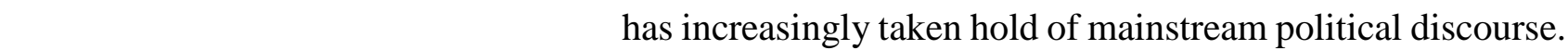

With European governments closely involved in the conflict since its outbreak, national news media in Europe have had a major stake in its coverage in at least two respects. Firstly, studies in popular geopolitics demonstrate that the geopolitical is not limited to the practices of state and military elites: the media contribute to the daily production of the geopolitical imagination, involving the drawing of boundaries between us I and others $\mathbb{I}$ as well as developing and disseminating interpretations of security and threat (Ó Tuathail, 1996; Mamadouh and Dijkink, 2006). Secondly, due to the proliferation and globalisation of media platforms and the emergence of almost real-time conflict reporting, conflicts have become increasingly mediatised and, therefore, the particular ways in which they are constituted in the media can have a significant bearing on their development and outcomes (Cottle, 2006; Hoskins and 29/RXJKOLQ (VNMU HW DO

By shaping elite and popular perceptions of the Ukrainian conflict and its participants, the news media can both legitimise and constrain the actual foreign policy decisions of European governments.

Thus, it is important to ask how the legitimation of particular political responses to a conflict may be supported by news frames that accentuate certain perspectives on reality over others. This paper draws from the field of popular geopolitics and focuses on the role of news frames - constituted in the interplay of visual and textual representations - in guiding the public interpretation of international conflicts and in rationalising foreign policy. We specifically inquire into the way in which four leading national newspapers in Western Europe have framed key events in the Ukrainian conflict and how these framings have aligned with European Union policies and positions. A broader concern is to ask to what extent national newspapers and journalists in Europe may be guided by and also FRQWULEXWH WR WKH QDWXUDOLVDWLRQ RI WKH QHZ FROG ZDUII DV D GRPLQDQW JHRS something which both positions and legitimises Western foreign policy.

\section{The geopolitics of conflict framing in foreign news}

Geopolitics, the practice and study of foreign policy in terms of political geography, occupies a central position in the global imagination, organising the world into a hierarchy of places, states and blocs 
(Agnew, 1998; Dalby, 2008). Within the geopolitical rationality, nations and regions are attributed unitary political, economic and military interests, and international relations becomes a global game in which clashes over these interests are played out (Kelly, 2006). National and international media are closely involved in the reproduction and normalisation of geopolitical narratives (Dittmer, 2010; Mamadouh and Dijkink, 2006; Sharp, 1996), and the relevance of the media constructions of geopolitical relations are accentuated at times of international conflict (Robison, 2004).

As the news media participate in the public sense-making of a conflict, they engage in the process of framing, a social and cognitive process in which a situation is defined in order to make human action possible (Goffman, 1986: 10-5HHVH 'HWHUPLQLQJZKDWLVEURXJKWLQWRDQDXGLHQFHףV ILHOGRISHUFHSWLRQI\%XWOHU LVDFHQWUDOHOHPHQW LQQHZVIUDPLQJDQGHQWDLO editorial decisions, including the selection of one viewpoint over others. News frames - as outcomes of this process - DUHLQWHUSUHWLYHSDFNDJHVI*DPVRQDQGORGLJOLDQLWKDWERWKMRXL and their readers depend on (Gitlin, 1980: 7), suggesting certain problem definitions, causal diagnoses, remedies and moral judgements of responsibility (Entman, 1993). Given the power of news frames to shape public interpretations of conflicts, their causes and the actors involved, the media may prescribe individual foreign policy decisions and delimit policy options, creating strong incentives for governments to intervene, or not, in favour of certain parties (e.g. Hammond, 2000; Robison, 2004; Roger, 2013).

Before the dissolution of the communist regimes in Eastern Europe, for decades the notion of the cold war had provided a powerful narrative of international relations with which to explain complex military and political events in international news and mainstream political discourse (Hanson, 1995; Norris, 1995). Prescribing an ideological and military rivalry between East and West, it not only aided in the orientation of Western foreign policy by placing the Soviet Union as the primary threat to national and international security (Meyer, 1995), but also helped legitimise and naturalise those policies in the public sphere (Herman and Chomsky, 2008). The fall of the Berlin Wall marked the demise of the cold war as a coherent narrative for mapping world politics, and reporting on international conflicts became inFUHDVLQJO\FRPSOH[IRU MRXUQDOLVPHJ+RVNLQV DQG2I/RXJK 2010; Norris, 1995).

However, having become deeply entrenched in the geopolitical imagination, the East-West division never completely withered away. With the deterioration of the relationship between the West and 
Russia over the past decade, cold war rhetoric has clawed its way back into international policy discourse and has been particularly notable during the 2008 Russo-Georgian war and most recently in the Ukrainian conflict (Monaghan, 2015; Sakwa, 2008). Consequently, the QHZFold wardmay be turning into a suggestive narrative for Western news media, with the potential consequence of contributing to the public legitimation of increasingly militaristic foreign policy positions in Europe.

\section{Material and method}

To study how the mainstream press in Western Europe frames the Ukrainian conflict, we analyse and compare the coverage of the conflict in four nationwide daily newspapers: The Guardian, Die Welt, Dagens Nyheter $(D N)$ and Helsingin Sanomat (HS). Ranking amongst the most widely read quality dailies in their countries ${ }^{1}$, the four are important national agenda-setters and thus have a key role in the reproduction of elite foreign policy discourses and geopolitical narratives. In the selection of suitable data for analysis, we set out from two main premises with regard to news framing. Firstly, we assumed that widely mediatised occurrences of violence, deaths and suffering have particular relevance in the public framing of a conflict as they tend to induce strong emotions, highlight questions of guilt and responsibility, and assert the sense that there is a moral obligation for people and governments to act (Chouliaraki, 2008; Parry, 2010). Accordingly, the data was gathered from four periods in the Ukrainian conflict between February 2014 and February 2015 (see Table 1). Each period was associated with violent incidents, armed combat and heightened international media exposure and could thus be considered key in shaping the dominant framings of the conflict in the newspapers.

Secondly, we presumed that various visual cues, most notably photographs and images, the placement of stories, the size of headlines and other typographical decisions, are key factors in influencing the salience and perceived importance of the stories in the newspapers (Coleman, 2010; Zillmann et al., 2001). Photographs, in particular, highlight the importance of stories, and, due to their power to induce emotions and their effectiveness in conveying implicit reality claims not easily recognised by the audience, they often direct the interpretation of news stories (Brantner et al., 2011; Messaris and Abraham, 2001). Accordingly, the significance of photographs has been subject to increasing attention in studies on the media coverage of war and crises (e.g. Butler, 2005; Pantti, 2013; Parry, 2010; Roger, 2013; Solaroli, 2011; Zelizer, 2004). Yet at the same time, the actual meaning given to images is partly dependent on how they are defined by their textual context, consisting primarily of the caption as well as the headline of the accompanying story (Coleman, 2010; Wilkes, 2015). It was thus our contention that the analysis of the Ukrainian conflict frames should take into account both 
the visual and textual cues of the articles because they work together to increase salience, create strong impressions and induce emotional engagement.

To facilitate such observation, we manually scanned the newspapers for articles that explicitly dealt with events connected to the conflict and decided to concentrate the analysis on those that contained images. The material from Die Welt, $D N$ and $H S$ was collected from the printed editions. However, due to the unavailability of its print edition to us when we conducted the study, we settled for reviewing the online versions of The Guardian articles ${ }^{2}$. For coding purposes, we regarded a combination of image(s) and text(s) laid out on a single page or a spread and covering the event from a relatively consistent point-of-view as our unit of analysis. As a result, a unit of analysis consisted of the main story, often written by a foreign correspondent from the scene of events, which was accompanied by one or several photos, and which could include a related comment, sidebar or background article. In total, the analysed material comprised 402 units of images and text from 38 days of coverage (see Table 1).

Table 1. Breakdown of the analysed data (total number of units of analysis: 402)

\begin{tabular}{|c|c|c|}
\hline $\begin{array}{l}\text { Data collection } \\
\text { period }\end{array}$ & Key events during the period & $\begin{array}{l}\text { Number of units of analysis per } \\
\text { newspaper }\end{array}$ \\
\hline $\begin{array}{l}\text { 21-27 February } \\
\text { ODLGDQII }\end{array}$ & $\begin{array}{l}\text { Maidan demonstrators and police shot during riots } \\
\text { in Kiev; Yanukovych flees to Russia; Parliament } \\
\text { votes to remove Yanukovych from power; protests } \\
\text { in eastern Ukraine; unrest and Russian activity in } \\
\text { Crimea }\end{array}$ & $\begin{array}{l}\text { Die Welt: } 16 \\
\text { DN: } 21 \\
\text { HS: } 21 \\
\text { The Guardian (online): } 32 \\
\text { Total: } 90\end{array}$ \\
\hline $\begin{array}{l}\text { 3-7 May } 2014 \\
\text { 2GHVVDII }\end{array}$ & $\begin{array}{l}\text { Violent riots in Odessa; anti-government activists } \\
\text { killed when trade union building set on fire; clashes } \\
\text { between insurgents and the army in eastern Ukraine }\end{array}$ & $\begin{array}{l}\text { Die Welt: } 12 \\
\text { DN: } 14 \\
H S: 9 \\
\text { The Guardian (online): } 15 \\
\text { Total: } 50\end{array}$ \\
\hline $\begin{array}{l}\text { 18-31 July } 2014 \\
0+\mathbb{I}\end{array}$ & $\begin{array}{l}\text { Malaysian Airlines flight MH17 shot down in } \\
\text { eastern Ukraine; the EU and the US set new } \\
\text { sanctions against Russia; intense battles in eastern } \\
\text { Ukraine }\end{array}$ & $\begin{array}{l}\text { Die Welt: } 32 \\
\text { DN: } 26 \\
\text { HS: } 28 \\
\text { The Guardian (online): } 82 \\
\text { Total: } 169\end{array}$ \\
\hline $\begin{array}{l}\text { 11-22 February } \\
\text { 0LQVNTI }\end{array}$ & $\begin{array}{l}\text { International ceasefire agreement signed in Minsk; } \\
\text { heavy fighting in eastern Ukraine; insurgents seize } \\
\text { the city of Debaltseve }\end{array}$ & $\begin{array}{l}\text { Die Welt: } 25 \\
\text { DN: } 14 \\
\text { HS: } 23 \\
\text { The Guardian (online): } 32 \\
\text { Total: } 94\end{array}$ \\
\hline
\end{tabular}

The framing analysis combined qualitative and quantitative methodology. Firstly, through a close reading of the material, we inductively worked out the principal news topics as defined by images and headlines, while also paying attention to earlier studies of conflict framing (Dimitrova and Strömbäck, 2005; Pantti, 2013; Parry, 2010). Subsequently, we coded each unit of analysis in the 
material separately, allowing us to uncover underlying patterns and differences in the coverage. In addition to documenting the primary visual and textual topics, the coding focused on the identification and representation of various actors, including protesters, soldiers, insurgents and political leaders in the images, headlines and captions. The coding of actor representations, on a positive-neutralnegative scale, was based on a consideration of the role the headline, caption or image attributed to the identified actors in the events reported (e.g. an aggressor, victim, protestor, mediator, hero). A representation of the people in the Maidan square, for instance, was considered positive if it presented them as peaceful protesters or victims of police violence, but negative if it focused attention on the armed and far-right elements among the protesters. A positive representation would associate the political power or leader with, for instance, peace efforts, widespread popular support or a position of power and influence among other leaders, whereas a negative representation would associate the leader with aggression, criminality, authoritarianism, isolation or a position of weakness. Each unit of analysis was coded by one of two coders, with a percent agreement between the coders (Neuendorf, 2002: 149) established at .80 on the primary visual and .80 on the primary textual topic, .91 for the general identification of actors and .82 for their representations.

In the third and final stage of analysis, we qualitatively worked out the dominant frames employed by the newspapers for each of the studied periods. Starting from the premises that news frames, on the one hand, develop within the broader political and cultural context in which the newspapers operate (cf. Reese, 2010; Vliegenthart and van Zoonen, 2011), and, on the other hand, are strategic devices that can be used to legitimise certain political outlooks and foreign policy decisions (Pan and Kosicki 2001; Reese 2010), we aimed at an overall interpretation of the news coverage in relation to the actions and aims of the parties to the conflict. Thus, we observed the news coverage against the background of the unfolding events in the Ukrainian conflict ${ }^{3}$, paying specific attention to official EU actions and positions on the developments ${ }^{4}$. By marking common patterns in the coverage and by testing our interpretations against the coding results from the previous stage of analysis, we thus worked out the dominant frames that were shared by the papers during each of the studied periods, while also noting LQGLYLGXDOQHZVSIgSFIdANETdivergences from the overall pattern.

\section{Analysis}

Since the beginning of the Ukrainian conflict, precipitated by the decision of the Ukrainian government to halt talks on an association agreement with the EU in November 2013, European leaders have been closely involved in its key events. On 21 February 2014, when both protesters and police were shot at on the streets of Kiev, the foreign ministers of Germany, France and Poland 
mediated negotiations between opposition leaders and 8NUDLQHFAsident, Viktor Yanukovych. However, within hours of the signing of an agreement on political reforms and new elections, Yanukovych fled the Ukrainian capital, armed protesters then stormed government buildings and the parliament and removed the president and the prime minister, Mykola Azarov, from power, installing Oleksandr Turchynov and Arseniy Yatsenyuk as interim president and prime minister, respectively. Whereas the Russian government reacted to the unexpected turn of events by condemning the regime change unconstitutional, and hence an effective coup, EU leaders dismissed the legal irregularities of the process and recognised the new government as legitimate. In subsequent months the EU, in coordination with the United States, kept the insolvent government afloat by extending it new loans through the IMF and, on 27 June 2014, sealed an association agreement with Ukraine.

\section{ODLGDQ3HRSOHIVWSing}

As a breaking news event attended by international media outlets, the chaotic developments surrounding the fall of Yanukovych presented a key moment in shaping public perceptions of the nature of the Ukrainian conflict. Overall, the studied newspapers shared many elements in their coverage of the event: all published dramatic imagery of violent street riots and the covered bodies of shot protesters, identified Maidan demonstrators as victims of police brutality, represented the ousted president as a corrupt dictator and featured heroic images of the liberated opposition leader Yulia Tymoshenko. The dominant framing of the events as a SHRSOHIVXSULWhQdeminiscent of the popular Western narratives of the Arab spring (Cottle, 2011) and built legitimacy for the new coalition in power. Photos of celebrating citizens and the lightly-DUPHGSHRSOHIVGHIOIQFHIRUFHVI guarding administrative buildings in the days following the regime change further reinforced the interpretation.

To differing extents the papers also brought attention to details which challenged the prevalent framing. The Guardian, $D N$ and $H S$ featured individual reports of anti-Maidan protests elsewhere in the country, thus acknowledging that not all Ukrainians were backing the regime change. In addition, $D N$ and $H S$ highlighted the existence of armed factions within the ranks of the Maidan demonstrators by picturing the arrival of the Lviv police force to support protesters. In one story, $H S$ even focused on the role of the paramilitary Right Sector groups in the momentary breakdown of social order. However, while these reports somewhat destabilised the dominant framing of the events as a SHRSOHIV revolution, they did not amount to a suggestion that the popular protests had been hijacked by organised far-right groups and turned into an armed grab of power - a framing highly influential, for 
instance, among the Russian media and political establishment (TASS 2014; see also Ishchenko, 2015: 155-6; Sakwa, 2015: 83-4).

Even dismissing the circumstances in which it overtook the state apparatus, the legitimacy of the new coalition in power in Ukraine and the (8IV support for it could be critically questioned. The far-right Svoboda party obtained three positions in the new government, one of its founders was put in charge of national security, and paramilitary Right Sector groups were incorporated into the military as independent battalions (Sakwa, 2015: 95-7, 158), raising questions about the adherence of the new UHJLPHWR citizens again - only this time in eastern Ukraine. Indeed, while protests in Kiev abated after the regime change, unrest continued in eastern parts of the country, where major sections of the population regarded the new government as illegitimate. As the anti-government movement grew, the most militant elements took advantage and transformed the protests into a full-scale rebellion, occupying administrative buildings and police headquarters in several cities before proclaiming

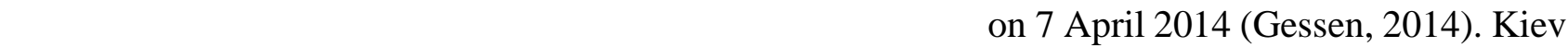
responded promptly by launching a military campaign against the insurgents, dubbing it DQDQWL WHUURULVWRSHUDWLRQI

\section{Odessa: Divided nation}

In early May 2014, tKHDUPIIIV VXUJHWRUHFDSWXIffiỏßaheWrebels coincided with riots in Odessa, where over 40 anti-government protesters died when trapped inside a burning trade union building. The newsSDSHUdrfferage of these events marked a significant shift in their framing of the conflict. Reports from Odessa and eastern Ukraine featured images of rioting activists, armed insurgents, Ukrainian soldiers, victims of violence and mourning civilians. In their stories from separatist-held cities, three of the four papers - Die Welt, DN and The Guardian - brought attention to the popular distrust of the Kiev government that was driving WKHUHEHOVIFDXVHrHdxWWKH made sure not to confuse anti-government struggles with a SHRSOHIVUHYROXWLRQAPredsQAWD regime. With the exception of one article in $D N$, there were no victimising or heroic images of antigovernment protesters; nor were there depictions of regime brutality. As a result, the dominant framing of the events was one of a divided nation being cleaved into two antagonistic groups and rapidly descending into a civil war.

Moreover, while this rift was presented from both sides, there were stark contrasts in the way the parties to the conflict were represented. Whereas the reporting on the February revolution identified 
with Maidan protesters and de-humanised the security forces, the coverage in May featured freshfaced Ukrainian servicemen and depicted the Odessa police as victims of protesters $\mathbb{I}$ aggression. Insurgents and anti-government activists were now pictured in threatening and aggressive poses. The observed pattern was repeated in the subsequent data collection periods. In the wake of the Minsk agreement in February 2015, all papers mostly covered the battles from the Ukrainian DUPIIV perspective, including humanising imagery of soldiers playing football during a brief ceasefire and of exhausted servicemen being transferred home after fleeing from Debaltseve. In contrast, images of insurgents appeared primarily in the aftermath of the MH17 disaster, when they were seen as mostly armed and masked, patrolling the crash site and confronting international investigators and aid workers. 7KHLU KDELWXDO ODEHOGR legitimation of the anti-government insurgency by implying its non-SDWULRWLF DUQLDQI nature (cf. Boyd-Barrett, 2015: 3-4).

\section{MH17: International atrocity}

The escalation of violence in eastern Ukraine did not prompt the EU to withdraw its support for the new government. On the contrary, WKH(8HIIHFWLYHO\DGRSWHGWKH8NUDLQLDQJRYHUQPHQW of presenting the armed insurrection as supported, if not entirely controlled, by the Kremlin. Following the seizure of Crimea by Russian forces and its subsequent annexation by Russia, the EU, together with the US, imposed economic sanctions against the Kremlin on 17 March 2014 (Sakwa, 2015: 187). Further rounds of sanctions were implemented in April and again in July following the downing of the Malaysian Airlines passenger plane MH17 (Anderson, 2015: 26). EU policy was now increasingly focused on Russia. The Kremlin was held responsible for further destabilisations in Ukraine, and Putin [s decisions were seen as either solving or escalating the conflict. Alongside the imposing of individual and sector-specific sanctions, EU leaders engaged in international diplomatic efforts, with marathon negotiations between chancellor Merkel and presidents Hollande, Putin and Poroshenko in Minsk on 12 February 2015 representing the most high-profile efforts since the beginning of the conflict. 
Table 2. 7KHDJJUHJDWHVKDUHVRIQDWLRQDOSROLWLFVILQWHUQDWLRQDOSROLWLFVIIDQGY of all visual and textual news topics in each of the analysed periods $(N=402)$.

\begin{tabular}{lrrrr} 
News topic & Maidan & Odessa & MH17 & Minsk \\
National politics (visual) & 46.7 & 18.0 & 6.0 & 6.4 \\
International politics (visual) & 13.3 & 14.0 & 21.4 & 34.0 \\
Violence and war (visual) & 24.4 & 50.0 & 58.3 & 46.8 \\
\hline National politics (textual) & 44.4 & 20.0 & 3.0 & 3.2 \\
International politics (textual) & 23.3 & 20.0 & 38.1 & 50.0 \\
Violence and war (textual) & 22.2 & 50.0 & 42.9 & 40.4
\end{tabular}

The EUIS policy of disregarding the domestic social bases of the eastern insurgency and the rendering of the Ukrainian conflict into a problem of primarily Russian intervention had clear parallels in the QHZVSDSHUVIIFRYHUDJHRIWKHARlQIRsmifharises the shares of the three most dominant visual and textual topics in each of the studied periods. The images of Ukrainian political leaders and civil society actors and the textual references to them in the headlines were labelled QDWLRQDOSROLWLFVI images of foreign leaders and references to foreign powers were coded under the topic of

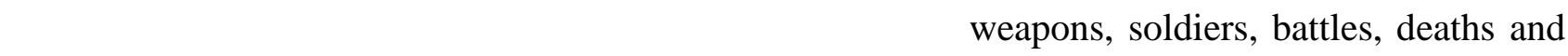
destruction were placed in the topic of YLROHQFHDQGZAdthe table indicates, a military focus took over the newspapers as the violence in eastern Ukraine escalated. Accordingly, developments were increasingly narrated in terms of advancing or retreating troops, clashes and battles, losses on both sides and civilian casualties. Simultaneously, there was a marked shift of focus away from Ukrainian political leaders and civil society and a move towards discussing the role of foreign powers in the conflict. After Odessa, the studied newspapers largely neglected the Ukrainian government as a significant actor in the conflict, and the political leadership of the Donbas rebels was almost entirely dismissed. No power within the country appeared to be responsible for the ongoing violence. Instead, the papers increasingly observed the conflict from the perspective of international politics, implying that Ukraine was a battleground for external powers.

The increasing focus on the international dimensions of the conflict in July 2014 was set against the shooting down of the Malaysian Airlines passenger plane. The now prevalent news topic of violence and war (see Table 2) was comprised of images of destruction, casualties and civilian mourning, yet this time the victims were overwhelmingly of Western European and Asian origin. The papers

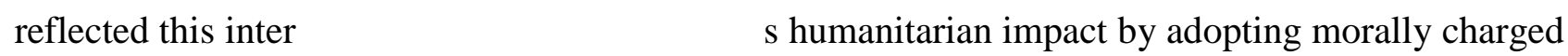
language. +HDGOLQHVVXFKDV:KR VKRW DW IOLJKWW@Iqlt, 19 July):KRNLOOHGWKHP"II 
(HS, 19 July), 3XWLQVHHPVWRKDYHEHHQFEXJWH, 19 July) and 0+WKHHYLGHQFH DJDLQVW5XVX/heDfuardian, 20 July) illustrate how the papers alerted audiences that a criminal act had been committed and directed the public to look for a party to blame.

This framing of the event as an international atrocity coincided with heightened attention on Russia. Table 3 compares the papers according to the frequency of articles - as a share of all articles they published in each period - that focused on Putin or Russia in their images or headline without referring to the presence of other actors. As the table indicates, close to every fourth article published in Die Welt, DN, and The Guardian over the MH17 period focused attention on Putin or Russia, constructing a strong association of Russia with responsibility for the disaster. Not only did the papers imply the criminDOLW $\backslash$ RI WKH.UHPQ4Qffss in Ukraine, the MH17 coverage reinforced the UHSUHVHQWDWLRQRI5XVVLDDV(XGIRSHeXter@HPizens as its victims. This cold war-like juxtaposition contributed to the seeming rationality of the new round of sanctions against Russia, swiftly announced by the EU on 24 July. In marked contrast to the other papers, $H S$ was notably restrained in singling out Russia during this period, publishing only two images of Putin and focusing its headlines on European political reactions to the incident.

Table 3. Articles emphasising 5XVVLDIVDFWLRQVDQG UHVSRQVLELOLW LiQ WEKAIFRQdOLFW images (as a proportion of all articles published by the paper in the period).

$\begin{array}{lrrrrr}\text { Newspaper } & \text { Maidan } & \text { Odessa } & \text { MH17 } & \text { Minsk } & \text { Total } \\ \text { The Guardian (online) } & 15.6 & 6.7 & 22.0 & 18.8 & 18.6 \\ \text { Die Welt } & 12.5 & 8.3 & 28.1 & 20.0 & 20.0 \\ \text { Dagens Nyheter } & 14.3 & 14.3 & 23.1 & 14.3 & 17.3 \\ \text { Helsingin Sanomat } & 9.5 & 0.0 & 7.1 & 8.7 & 7.4\end{array}$

Minsk: Proxy war

If the MH17 coverage directed attention to the intervention of foreign powers in the Ukrainian conflict, the Minsk negotiations in February 2015 crystallised their roles in it. During this period, as Table 2 indicates, the visual and textual emphasis on warfare in the papers was complemented with attention on foreign political leaders and the simultaneous disregard of Ukrainian political actors. The marginalisation of Poroshenko, the total dismissal of the presence of the rebel leadership, and the emphasis on Putin, Merkel and Hollande in the coverage of the ceasefire negotiations reinforced the sense of outside powers overseeing the actual fighting in Ukraine. The coverage thus amounted to a 
cold war-like framing of the events as a proxy war in which the Ukrainians were the fighters and victims of a confrontation between the Western European leaders and Putin.

As was the case in the MH17 period, three of the four papers frequently directed attention toward 5XVVLD\$1e and responsibility in the conflict (see Table 3). DN cynically declared 3XWLQDVWKH ZLQQHUIRIWKHZHDNSHDFHDJUHHPHQWIIWKDWZDVXQOLNHOIWRHQGWKHILJKWLQJLQ8N 2015). The paper thus continued its consistent pattern of implicating Putin as the driver of violence in Ukraine by use of KHDGOLQHVVXFKDV0RVFRZIVPHQVKRRWZKLOH3XWLQIROORZVWKH2O )HEUXDU16WRSWKH.UHPOLQSUHGDWRUI0DWQG3XWLQ IVPLVVLOHVI-XO2014). Die

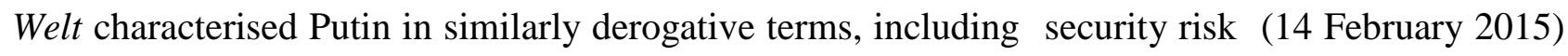
and power-obsessedTI (15 February 2015), and it also assumed the role of the E8Is and its own

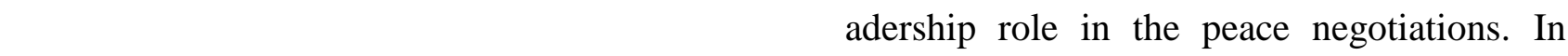
comparison, The Guardian was more restrained in its representations of Putin during this period and took a critical distance from Western leaders, too, presenting a rather non-partisan view of the geopolitics of the conflict. $H S$, in turn, was again careful not to demonise or isolate Putin, but the paper nevertheless aligned itself with the Western perspective by joining its German counterpart in DQH[DOWDWLRQRIOHdeAslelOSWSHDFHHIIRUWBVFbruary).

\section{Discussion}

As far as the framing of a foreign conflict is concerned, news is a fragmentary entity. The coverage of events in any newspaper always offers several alternative and often contradictory readings (Vliegenthart and van Zoonen, 2011). Yet we found common patterns in the framing of the Ukrainian conflict, which were reproduced to varying degrees of forcefulness in the studied newspapers. Firstly, Ukrainian actors, including political leaders, demonstrators, police, volunteer militias and military servicemen, were mostly presented in a positive manner and their perspectives were identified with

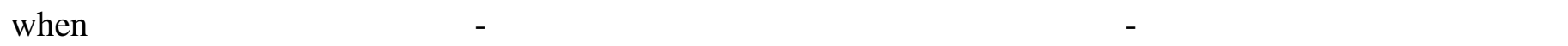
represented as aggressive and threatening and their viewpoints remained largely obscure. The notable exception to this general rule was ordinary citizens; when identified as the private opinions of FLYLOLDQVII YLHZV DQWLWKHWLFDO WR WKW estethWLPPDIfeR IIWEKHovernment were validated. Secondly, Russian involvement in the events was emphasised above all other powers, including the Ukrainian government and rebel leadership. Coupled with primarily negative representations of Putin, the focus on Russia tended to suggest that only one party was to blame for the conflict and that this party therefore held the keys to its solution. It also undermined framings 


\section{ZKLFKZRXOGTXHVWLRQWKHOHJLWLPDFIRI8NUDLQHIIVSUHVHQWUHJLPHDQGWKHUROHR}

NATO in increasing international tensions and divisions within Ukraine.

Due to the tendency of the elite press to frame foreign news in close concordance with national foreign policy establishments (Herman and Chomsky 2008; Lawrence, 2010), the extent to which the four papers conformed to or deviated from this shared framing pattern may reflect some of the national differences within the EU concerning the Ukrainian conflict. Of the studied countries, the UK and Sweden, in particular, have assumed active roles in driving EU sanctions against Russia (ECFR, 2015), whereas the German and Finnish governments have been more restrained in this regard (Pond and Kundnani, 2015; Rossi, 2014). Indeed, EU policy making in the conflict has been internally conflicted due to the vastly differing histories, positions and foreign policy traditions of its member states with regard to Russia, and to some degree, these national policy preferences may be reflected in the studied newspapers. In particular, this may be the case with Helsingin Sanomat IVnotable moderate line, compared to the other newspapers, in its representations of 5XVVLDIV UROHLQWKH conflict. $^{5}$

Yet despite their differences, the papers $\llbracket$ dominant framing patterns largely aligned them with the WHVWHUQISR Vh tMeIcR@lict while alienating Russia. During its various stages, official EU policy in the Ukrainian conflict has primarily consisted of supporting the Maidan movement; politically RSSRVLQJWKH<DQXNRYVFKJRYHUQPHQWOHJLWLPLVLQJWKHUHJLPHFKDQXIRQGBQWDLHप leadership; finalising the association agreement with Ukraine; supporting the Ukrainian government DQGSURYLGLQJLWZLUKORR(D) and extending economic and political sanctions against Russia (Anderson, 2015; Sakwa, 2015). These policies, coordinated with the United States, have partly rested on favourable public opinion within Western Europe, which is based on a perception of the Russian president as the culprit and aggressor and the Ukrainian government as the victim of a foreign attack (Pew Research Center, 2015). Our analysis suggests that the studied newspapers have framed key events in the conflict in ways that have largely validated such interpretations.

The limited size of the analyzed material cautions against generalizing such conclusions, and research with larger data sets would be required to complement the findings of this study. Neither are the results meant to be read as an assessment of how the national news media of the studied countries as a whole have framed the conflict. Nevertheless, our study seems to corroborate earlier findings 
concerning the role of the media in actively reproducing elite foreign policy frames as well as dominant geopolitical imaginaries (Ojala, 2011; Reese, 2010; Robison, 2004; Tsatsou and Armstrong, 2014). According to this perspective, the news media have largely promoted versions of events that legitimise the EUIVposition on WKHFRQIOLFWEHFDXVHWKHQHZFROGZDU\&dDVDJHRSR narrative has provided the journalists with a simple and highly suggestive prism through which to report and explain the events and what the conflict is about. Indeed, the findings indicate that, as the Ukrainian conflict has evolved, the news media have adopted an increasingly consistent perspective on the events so as to reproduce an underlying geopolitical narrative of the conflict in terms of a superpower conflict between East and West. A case for future research is to delve into specific journalistic mechanisms and practices - including the socialisation of journalists into professional cultures and their sourcing practices - through which geopolitical imaginaries become embedded in international journalism as heuristic devices that lead to their reproduction as news frames.

In this naturalisation of geopolitical interests and identities (Mamadouh and Dijkink, 2006), the newspapers should not be considered merely as passive message carriers in the service of national and European elites. The prevalence of violent imagery in the visual framing of the conflict, for instance, suggests the newspapers have been active in creating a sense of urgency, thus potentially contributing to the public pressure and sense of moral obligation for EU governments to intervene in the conflict (cf. Chouliaraki, 2008; Hammond, 2000).

Moreover, instead of merely legitimising EU policies, the press may have played a part in directing the policy response by restricting the range of available policy options. By promoting simplistic representations of geopolitical realities and Putin as the enemy of the West, the national news media in Europe may be contributing to a climate of public opinion in which EU leaders need to be careful not to appear to be appeasing Russia. More fundamentally, national newspapers may be reproducing a geopolitical narrative which renders it rational to continue to escalate a NATO-Russia conflict, despite frequent warnings of where such military logic can lead (Frear et al., 2015). If the QHZFROG

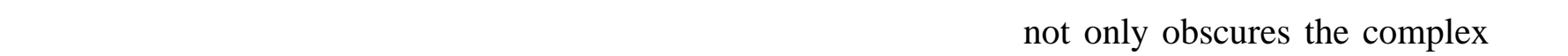
international security questions of today (Monaghan, 2015), but it also hinders a deeper understanding of the Ukrainian conflict by reducing it to a theatre for the clash of seemingly irreconcilable EastWest divisions. 


\section{Notes}

1. Die Welt is the third-largest national daily in Germany with a circulation of 190,000; The Guardian ranks third among the British quality dailies with a circulation of 164,000; Dagens Nyheter has the largest circulation among the Swedish morning newspapers with 280,000 copies; and Helsingin Sanomat is the largest subscription newspaper in Finland with a circulation of 267,000.

2. Using the daily archive provided by theguardian.com (see http://www.theguardian.com/theguardian), we selected only those online articles which also appeared in the printed edition of the newspaper. The online versions of the articles tend to differ from those published in print with regard to length, headlines and photos used, and they also sometimes contained videos, which were included in the analysis. The conclusions concerning The Guardian articles are therefore only partly applicable to the printed edition of the paper.

3. The literature on the Ukrainian conflict consulted at this stage consisted of Sakwa (2015), Ishchenko (2014; 2015), Gessen (2014), Pikulicka-Wilczewska and Sakwa (2015), Boyd-Barrett (2015), and Haukkala (2015), along with a number of newspaper and magazine articles by foreign policy experts.

4. Our observations on EU policy and on its positions on the conflict are based on research literature (see note 2), as well as on the official decisions and statements of the EU Council of Ministers and Foreign Affairs Council during the analysed events.

\section{Paper-VSHFLILFHGLWRULDOVODQWVPDWDOVRDFFRXQWIRUVRPHRIWKHSHUFHLYHGGLII} coverage as a market liberal newspaper can be read as an expression of a committed pro-Western stance within a highly charged political debate in Germany (Neukirch, 2014), and DN's demonising representations of Putin can be understood as the intentional choice of a paper which has actively 
promoted NATO membership for Sweden (Nohrstedt and Ottosen, 2014: 105).

\section{References}

Agnew J (1998) Geopolitics: Re-visioning World Politics. London: Routledge.

Anderson P (2015) Incommensurate Russia. New Left Review 94: 5-43.

Boyd-Barrett O (2015) Ukraine, mainstream media and conflict propaganda. Journalism Studies, DOI: 10.1080/1461670X.2015.1099461.

Brantner C, Lobinger K and Wetzstein I (2011) Effects of visual framing on emotional responses and evaluations of news stories about the Gaza conflict 2009. Journalism \& Mass Communication Quarterly 88(3): 523-540.

Butler J (2005) Photography, war, outrage. PMLA 120(3): 822-827.

Chouliaraki L (2008) The symbolic power of transnational media. Managing the visibility of suffering. Global Media and Communication 4(3): 329-351.

Coleman R (2010) Framing the pictures in our heads. Exploring the framing and agenda-setting effects of visual images. In D’Angelo P and Kuypers JA (eds) Doing News Framing Analysis. New York: Routledge, pp. 233-261.

Cottle S (2006) Mediatized Conflict: Developments in Media and Conflict Studies. Maidenhead: Open University Press.

Cottle S (2011) Media and the Arab uprisings of 2011. Journalism 12(5): 647-659.

Dalby S (2008) Imperialism, domination, culture: The continued relevance of critical geopolitics. Geopolitics 13(3): 413-436.

Dimitrova DV and Strömbäck J (2005) Mission accomplished? Framing of the Iraq War in the elite newspapers in Sweden and the United States. International Communication Gazette 67(5): $399-417$.

Dittmer J (2010) Popular Culture, Geopolitics, and Identity. Lanham: Rowman \& Littlefield. 
ECFR (2015) European Foreign Policy Scorecard 2015. London: European Council on Foreign Relations. Available at: http://www.ecfr.eu/page/-/ECFR125_SCORECARD_2015.pdf.

Entman R (1993) Framing: Towards clarification of a fractured paradigm. Journal of Communication 43(4): 51-58.

Eskjær M, Hjarvard SA and Mortensen M (2015) The Dynamics of Mediatized Conflict. New York: Peter Lang.

European Commission (2016, January) Humanitarian aid and civil protection. ECHO Factsheet. Available at: http://ec.europa.eu/echo/files/aid/countries/factsheets/ukraine_en.pdf

Frear T, Kearns I and Kulesa L (2015) Preparing for the worst: Are Russian and NATO military exercises making war in Europe more likely? European Leadership Network Policy Brief, August 2015. Available at: http://www.europeanleadershipnetwork.org/preparing-for-theworst-are-russian-and-nato-military-exercises-making-war-in-europe-more-likely_2997.html.

Gamson WA and Modigliani A (1989) Media discourse and public opinion on nuclear power: A constructionist approach. American Journal of Sociology 95(1): 1-37.

Gessen K (2014) Why not kill them all? London Review of Books 36(17): 18-22.

Gitlin T (1980) The Whole World Is Watching. Mass Media in the Making and Unmaking of the New Left. Berkeley: University of California Press.

Goffman E (1986) Frame Analysis: An Essay on the Organization of Experience. Boston: Northeastern University Press.

Hammond 3*RRGYHUVXVHYLOIDIWHUWKHFROGæB্bvo and the moralisation of war reporting. Javnost - The Public 7(3): 19-37.

Hanson E (1995) International news after the cold war: Continuity or change? Political Communication 12(4): 351-355. 
Haukkala H (2015) From cooperative to contested Europe? The conflict in Ukraine as a culmination of a long-term crisis in EU-Russia relations. Journal of Contemporary European Studies 23(1): $25-40$.

Herman ES and Chomsky N (2008 [1988]) Manufacturing Consent. The Political Economy of the Mass Media. London: Bodley Head.

Hoskins A and 2I/RXJKOLß)(2010) War and Media. The Emergence of Diffused War. Cambridge: Polity.

,VKFKHQNR98NUDLQHTVIUDFWXUAHW Left Review 87: 7-33.

Ishchenko V (2015) Maidan mythologies. New Left Review 93: 151-159.

Kelly P (2006) A critique of critical geopolitics. Geopolitics, 11(1): 24-53.

Lawrence RG (2010) Researching political news framing: Established ground and new horizons. In 'II\$QJHOR3 and Kuypers JA (eds) Doing News Framing Analysis. New York: Routledge, pp. $265-285$.

Legvold R (2014) Managing the new Cold War. Foreign Affairs, July/August. Available at: https://www.foreignaffairs.com/articles/united-states/2014-06-16/managing-new-cold-war. Mamadouh V and Dijkink G (2006) Geopolitics, international relations and political geography: The politics of geopolitical discourse. Geopolitics 11(3): 349-366.

Messaris P and Abraham L (2001) The role of images in framing news stories. In Reese SD, Gandy Jr OH and Grant AE (eds) Framing Public Life. Mahwah: Lawrence Erlbaum, pp. 215-226. Meyer D (1995) Framing national security: Elite public discourse on nuclear weapons during the cold war. Political Communication 12(2): 173-192.

Monaghan A 1HZFROGZDUI"\$EXVLQJKLVWRUIP isunderstanding Russia. London: Chatham House, the Royal Institute of International Affairs.

Neuendorf KA (2002) The Content Analysis Guidebook. Thousand Oaks: Sage. 
Neukirch R (2014) Is Germany a country of Russia apologists? Spiegel Online, 31 March. Available at: http://www.spiegel.de/international/germany/prominent-germans-have-understanding-forrussian-annexation-of-crimea-a-961711.html.

Nohrstedt SA and Ottosen R (2014) New Wars, New Media and New War Journalism. Gothenburg: Nordicom.

Norris P (1995) The restless searchlight: Network news framing of the post cold-war world. Political Communications 12(4): 357-370.

Ó Tuathail G (1996) Critical Geopolitics: The Politics of Writing Global Space. Minneapolis: University of Minnesota Press.

Ojala M (2011) Mediating global iPDJLQDUL2EDPDIAGGUHVVWRWKH0XKOICAGILQWKH Western European press. Journalism Studies 12(5): 673-688.

Pan Z and Kosicki GM (2001) Framing as a strategic action in public deliberation. In Reese SD, Gandy Jr OH and Grant AE (eds) Framing Public Life. Mahwah: Lawrence Erlbaum Associates, pp. 35-65.

Pikulicka-Wilczewska A and Sakwa R (eds) Ukraine and Russia: People, Politics, Propaganda and Perspectives. Bristol: E-International Relations.

Pantti M (2013) Seeing and not seeing the Syrian crisis: New visibility and the visual framing of the Syrian conflict in seven newspapers and their online editions. JOMEC Journal: Issue 4 (November).

Parry K (2010) A visual framing analysis of British press photography during the 2006 IsraelLebanon conflict. Media, War \& Conflict 3(1): 67-85.

Pew Research Center (2015) NATO Publics Blame Russia for Ukrainian Crisis, but Reluctant to Provide Military Aid. Available at: http://www.pewglobal.org/files/2015/06/Pew-ResearchCenter-Russia-Ukraine-Report-FINAL-June-10-2015.pdf 
3RQG(DQG.XQGQDQL+*HUPDQIIIV real role in the Ukraine crisis. Foreign Affairs,

March/April. Available at: https://www.foreignaffairs.com/articles/eastern-europecaucasus/germany-s-real-role-ukraine-crisis.

Reese SD (2001) Prologue-Framing public life: A bridging model for media research. In Reese SD, Gandy Jr OH and Grant AE (eds). Framing Public Life. Mahwah: Lawrence Erlbaum Associates, pp. 7-31.

Reese SD (2010) Finding frames in a web of culture: The case of the war on tHUURU,Q'II\$QJH®R and Kuypers JA (eds) Doing News Framing Analysis. New York: Routledge, pp. 17-42.

Robison B (2004) Putting Bosnia in its place: Critical geopolitics and the representation of Bosnia in the British print media. Geopolitics 9(2): 378-401.

Roger N (2013) Image Warfare in the War on Terror. London: Palgrave Macmillan.

Rossi J (2014) Finland feels EU should go slow on Russia sanctions. The Wall Street Journal, 8 September. Available at: http://www.wsj.com/articles/finland-feels-eu-should-go-slow-onrussia-sanctions-1410202205 (accessed 4 September 2015).

Rutland P (2015) An unnecessary war: The geopolitical roots of the Ukraine crisis. In PikulickaWilczewska A and Sakwa R (eds) Ukraine and Russia: People, Politics, Propaganda and Perspectives. Bristol: E-International Relations, pp. 129-140.

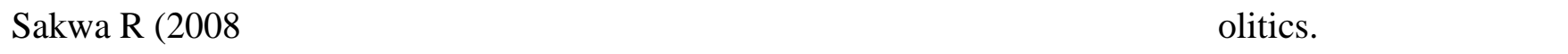
International Affairs: 84(2), 241-267.

Sakwa R (2015) Frontline Ukraine. Crisis in the Borderlands. London: I.B. Tauris.

Sharp JP (1996) Hegemony, popular culture and geopolitics: WKH5HDGHUgIV'LJHVWDQGWKH construction of danger. Political Geography, 15: 557-570.

Solaroli M (2011) Mediatized conflicts, performative photographs and contested memory: The Abu *KUDLEVFDQGDODQGWKHLFRQLFVWUXJJOHRYHUWKHPHDQURUYRdAXIKIAZdiURQWHU and Communication 7(3): 245-250. 
TASS (2014) Russian takeover of Crimea unlikely - Putin. 4 March. Available at: http://tass.ru/en/russia/721957

Tsatsou P and Armstrong CD (2014) Responsibility to report: The politics of British press reporting of the Darfur humanitarian crisis. Global Media and Communication 10(2): 193-219.

Vliegenthart R and van Zoonen L (2011) Power to the frame: Bringing sociology back to frame analysis. European Journal of Communication 26(2): 101-115.

Wade RH (2015) Reinterpreting the Ukraine conflict: The drive for ethnic subordination and existential enemies. Challenge 58(4): 361-371.

Wilkes R (2015) Political conflict photographs and their keyword texts. Journalism Studies, DOI:10.1080/1461670X.2015.1006908.

Wilson A (2009) The Ukrainians: Unexpected Nation. 3rd. Ed. New Haven: Yale University Press.

Zelizer B (2004) When war is reduced to a photograph. In Allan S and Zelizer B (eds) Reporting War: Journalism in Wartime. Abingdon: Routledge, pp. 115-135.

Zillmann D, Knobloch S and Yu, HS (2001) Effects of photographs on the selective reading of news reports. Media Psychology 3(4): 301-324. 